\title{
Utilization of Solar Energy on 10 GT Fishing Vessels as Alternative Electricity Facilities at PPI Cituis Tangerang Regency
}

\author{
Bambang Sudjasta *, Sugeng Prayitno, M. Rusdy Hatuwe \\ Ship Engineering Study Program, Faculty of Engineering, UPN "Veteran" Jakarta, Indonesia
}

\begin{abstract}
The purpose of this study is to design or design a $10 \mathrm{GT}$ fishing vessel for the territorial waters of Pakuhaji District, Tangerang Regency. This research is expected to provide benefits in getting the shape and size of fishing vessels that are suitable for the territorial waters, providing input to the Tangerang Regency Government, especially the Fisheries Service in the context of increasing the empowerment of fishing communities. The designed ship is planned to use materials / raw materials made of aluminum, fiberglass or wood. Material / raw material for the ship is still easy to find in the Greater Jakarta area. The design of the fishing vessel includes determining the basic size, making line drawings, preparing general plans, construction designs, stability diagrams, engine power, electricity, tonage and stability. The results of the maximum electricity demand is 495 Watt, 2 solar panels, and 3 batteries / batteries.
\end{abstract}

Keywords: Fishing vessels, Solar energy, Welfare, environmentally friendly

\section{Introduction}

The potential of Indonesia's marine fisheries resources is 6.6 million tons / year, but only a portion of which can be captured by Indonesian fishermen is \pm 4.7 million tons / year, partly stolen by fishermen of neighboring countries. This is due to the limited number and large size of fishing vessels in operation. According to the Head of the Maritime and Fishery Human Resources Development Agency, the Indonesian Ministry of Maritime Affairs and Fisheries estimates that the potential number of fish resources allowed in the Indonesian fisheries management area reaches 12.5 million tons [6].

One area that has potential for capture fisheries is Pakuhaji District, Tangerang Regency, Banten Province. Pakuhaji Subdistrict has a coastal area which is directly facing the Java Sea. This region has a coastline of \pm 6 ( $\mathrm{six}$ ) kilometers. This region has a Cituis Fish Landing Base (PPI), precisely located in Surya Bahari Village.

Surya Bahari Village Area, Pakuhaji District, Tangerang Regency has great potential for capture fisheries. In this region, there is a Fish Landing Base (PPI) which is capable of anchoring fishing vessels up to a maximum size of 10 Gross Tonnage (GT) vessels. The fishing boat with a size of 10 GT is intended for inland waters and archipelago waters. In order to improve the capabilities of the fishermen in the Pakuhaji

\footnotetext{
* Corresponding author : bambangsudjasta@upnvj.ac.id
}

District, fishing vessels need to be built that are suitable for this region and are energy efficient. If the design / construction and construction of fishing vessels can be realized, then in turn the welfare of the fishermen in this region will increase [1].

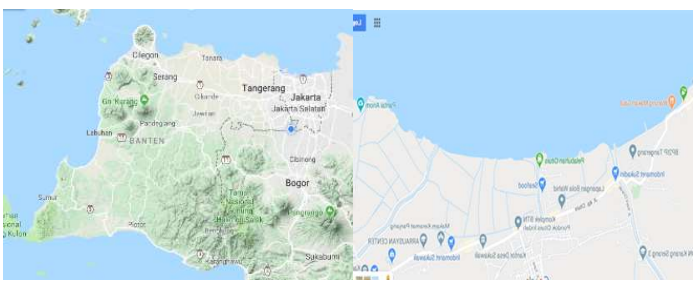

Fig.1. Map of PPI Cituis

The designed ship is planned to use materials that are generally used to build ships with a relatively small size [8]. The design of the ship includes determining the basic size, making line drawings, preparing general plans, construction designs, stability diagrams, engine power, solar energy, and tonage.

To meet the criteria of energy saving and environmentally friendly, the electricity generating equipment for lighting at night and other purposes, the designed ship is planned to use solar energy [4].

The length of the PPI Cituis jetty is approximately 150 meters, with a pool depth of less than $70 \mathrm{~cm}$. Can accommodate \pm 10 fishing vessels be measuring an average of $10 \mathrm{GT}$. Capture land area for catching fish is 
not more than 5 hectares. From the limitations of the available landing facilities, a fishing boat can be designed for a maximum of $10 \mathrm{GT}$. The problem of electrical energy for lighting purposes during nighttime operations and other electricity needs is a separate problem, which has so far been using a generator constrained by the limited supply of expensive fuel oil. The use of stum storage batteries is identified to be easily damaged due to frequent loading and unloading at the time of filling the strum. To overcome the problems of electrical energy with the alternative use of solar panel installation as a provider of electrical energy as a substitute for the previous electrical energy system.

To design a fishing vessel that will be operated, especially in the waters of Tangerang Regency, there are certainly some things that become the basis of reference. One such reference is the criteria / port class [7].

Table 1. Characteristics of PPI

\begin{tabular}{|c|l|l|}
\hline No & $\begin{array}{l}\text { Fisheries Port } \\
\text { Criteria }\end{array}$ & PPI \\
\hline 1 & $\begin{array}{l}\text { Operational areas of } \\
\text { fishing vessels served }\end{array}$ & $\begin{array}{l}\text { inland and } \\
\text { Archipelago Sea }\end{array}$ \\
\hline 2 & $\begin{array}{l}\text { Ship / berthing } \\
\text { facilities }\end{array}$ & $3-10 \mathrm{GT}$ \\
\hline 3 & $\begin{array}{l}\text { Pier length and depth } \\
\text { of pond }\end{array}$ & $50-100 \mathrm{~m}$ dan $>2 \mathrm{~m}$ \\
\hline 4 & $\begin{array}{l}\text { Capacity to } \\
\text { accommodate ships }\end{array}$ & $\begin{array}{l}>60 \mathrm{GT} \text { (equivalent } \\
\text { to 20 vessels 3 GT) }\end{array}$ \\
\hline 5 & Volume of landed fish & - \\
\hline 6 & Fish exports & Non \\
\hline 7 & $\begin{array}{l}\text { Land area for } \\
8\end{array}$ & $\begin{array}{l}\text { Facilities Non } \\
\text { developing fishery } \\
\text { products quality }\end{array}$ \\
\hline 9 & $\begin{array}{l}\text { Spatial (zoning) } \\
\text { processing Non } \\
\text { development of the } \\
\text { fishing industry }\end{array}$ \\
\hline
\end{tabular}

The purpose of this study is to design or design a 10 GT fishing vessel for the territorial waters of Pakuhaji District, Tangerang Regency. This research is expected to provide benefits in getting the shape and size of fishing vessels that are suitable for the territorial waters, providing input to the Tangerang Regency Government, especially the Fisheries Service in the context of increasing the empowerment of fishing communities. Fishing Vessel (Fishing Vessel) is a type of fishing vessel specifically used for catching fish, including storing, storing, cooling or preserving [12]. Fishing gear that is only allowed to be used in waters around the ZEEI line is a type of trawl and gill net.

The Fish Landing Base (PPI) is a Type D. fishing port. This fishing port has a land area of 2-5 Ha, and is designed to serve fishing vessels measuring 3 - 10 GT. This fishing port can accommodate 6 ships or $60 \mathrm{GT}$ at a time. This fishing port serves fishing vessels operating in coastal / inland waters and archipelago waters [3].

\section{METHODOLOGY}

\subsection{Reasearch Flowchart}

Research methods in the Utilization of Solar Energy on 10 GT Fishing Vessels as Alternative Electricity Facilities at PPI Cituis Tangerang Regency include the research flow and a description of the research flow as shown in Figure 2.

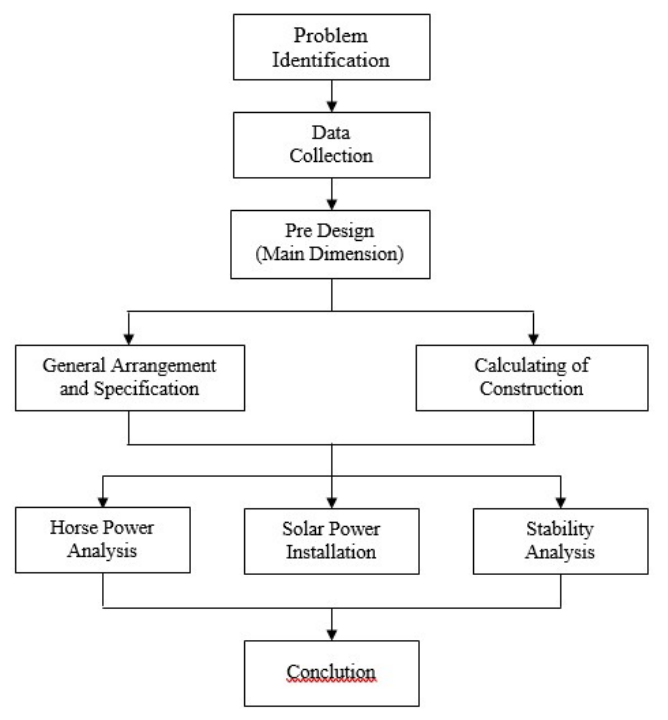

Fig.2. Flowchart of Research Methods

\subsection{Research Methods}

Table 2. Research Methods Description

\begin{tabular}{|l|l|l|}
\hline \multicolumn{1}{|c|}{ Activities } & \multicolumn{1}{c|}{ Method } & \multicolumn{1}{c|}{ Output } \\
\hline $\begin{array}{l}\text { Problem } \\
\text { identification } \\
\text { and Data } \\
\text { Collection }\end{array}$ & $\begin{array}{l}\text { Literature and } \\
\text { survey }\end{array}$ & $\begin{array}{l}\text { 10 GT fishing } \\
\text { vessel survey data } \\
\text { as a comparison } \\
\text { and PPI Cituis data }\end{array}$ \\
\hline Pre-design & $\begin{array}{l}\text { Comparison } \\
\text { Ratio Methods, } \\
\text { The Principal } \\
\text { Size ratio : } \\
\text { L/B, B/T, D/T }\end{array}$ & $\begin{array}{l}\text { The Principal Size } \\
\text { of ship : Loa; } \text { Lpp } \\
\text {; Lwl ; B; D; T. }\end{array}$ \\
\hline $\begin{array}{l}\text { Estimated } \\
\text { Vessel Weight }\end{array}$ & $\begin{array}{l}\text { Benchmarks } \\
\text { and general } \\
\text { formulas }\end{array}$ & $\begin{array}{l}\text { Deadweight and } \\
\text { Lightweight }\end{array}$ \\
\hline $\begin{array}{l}\text { Determination } \\
\text { of the General } \\
\text { Arrangement }\end{array}$ & $\begin{array}{l}\text { General } \\
\text { regulation of } \\
\text { ships and CAD } \\
\text { software }\end{array}$ & $\begin{array}{l}\text { Figure concept of } \\
\text { General } \\
\text { Arrangement }\end{array}$ \\
\hline $\begin{array}{l}\text { Determination } \\
\text { of Ship }\end{array}$ & $\begin{array}{l}\text { General } \\
\text { regulation of } \\
\text { Equipment and } \\
\text { Specifications } \\
\text { selection of } \\
\text { ship equipment } \\
\text { including } \\
\text { electrical } \\
\text { systems }\end{array}$ & $\begin{array}{l}\text { Ship moving } \\
\text { system equipment ; } \\
\text { accommodation; } \\
\text { mooring system; } \\
\text { safety ; Equipment } \\
\text { operation } \\
\text { specifications and } \\
\text { procedures. }\end{array}$ \\
\hline $\begin{array}{l}\text { Degulations of } \\
\text { the Ship } \\
\text { of Constermination of } \\
\text { Classification } \\
\text { Bureau } \\
\text { baffles, frames } \\
\text { hull plates, deck } \\
\text { plates. }\end{array}$ \\
\hline
\end{tabular}




\begin{tabular}{|l|l|l|}
\hline $\begin{array}{l}\text { Tonnage } \\
\text { Calculation }\end{array}$ & IMO Standard & $\begin{array}{l}\text { Magnitude of } \\
\text { volume of the } \\
\text { entire room }\end{array}$ \\
\hline $\begin{array}{l}\text { Determination } \\
\text { of Driving } \\
\text { Power }\end{array}$ & $\begin{array}{l}\text { Using } \\
\text { Hullspeed } \\
\text { analysis }\end{array}$ & $\begin{array}{l}\text { Ship resistance and } \\
\text { horsepower of a } \\
\text { certain speed, BHP. }\end{array}$ \\
\hline $\begin{array}{l}\text { Calculation of } \\
\text { solar energy and } \\
\text { its installation }\end{array}$ & $\begin{array}{l}\text { General } \\
\text { calculation }\end{array}$ & $\begin{array}{l}\text { The amount of } \\
\text { power generated } \\
\text { and the installation } \\
\text { circuit }\end{array}$ \\
\hline $\begin{array}{l}\text { Stability } \\
\text { Calculations }\end{array}$ & $\begin{array}{l}\text { Stability } \\
\text { Theory and } \\
\text { Trim }\end{array}$ & $\begin{array}{l}\text { KG and LCG are } \\
\text { empty and full } \\
\text { conditions. GZ } 0^{0} \\
\text { to sink angle. }\end{array}$ \\
\hline
\end{tabular}

\section{RESULTS AND DISCUSSION}

\subsection{Cituis Fish Landing Base (PPI)}

The management and guidance of PPI Cituis is under the Tangerang Regency Maritime and Fisheries Office. The role of PPI Cituis is to advance capture fisheries in the area which include aspects of production, processing and marketing. Its operation is greatly influenced by the catch landed. The capacity of the PPI Cituis facility will affect the smooth operation of port activities to fulfill its functions optimally. PPI Cituis is one of the seven PPI in Tangerang Regency that contributes to the Tangerang Regency PAD. The facilities, production and requirements of PPI Cituis are described as in table 3 below.

Table 3. PPI Cituis

\begin{tabular}{|c|l|l|}
\hline No & $\begin{array}{l}\text { Facility } \\
\text { Infrastructure }\end{array}$ & Description \\
\hline 1. & Berth length & \pm 60 meter \\
\hline 2. & Berth pool & $\begin{array}{l}\text { High } \pm 2,5 \text { meter } \\
\text { Low } \pm 1,5 \text { meter }\end{array}$ \\
\hline 3. & Ship visits & \pm 30 ships / day \\
\hline 4. & Fishing gear & Sondong (trawl push) \\
\hline 5. & Fish catches & $\begin{array}{l}\text { Shrimp, bilis, petek, } \\
\text { and tembang }\end{array}$ \\
\hline 6. & $\begin{array}{l}\text { The number of } \\
\text { catches }\end{array}$ & $\pm 120 \mathrm{~kg} /$ ship / day \\
\hline 7. & Fuel oil & 7500 liters / day \\
\hline 8. & Ice blocks & \pm 60 block / day \\
\hline
\end{tabular}

Almost all PPI Cituis facilities are considered to be adequate, except for the capacity to accommodate vessels that need to be added, because sometimes the ship that will lean must wait in line.

\subsection{General Arrangement}

\subsubsection{Main Dimension}

A general plan is presented to explain the design of a 10 GT fishing boat with a single engine (1) 54 HP diesel engine and can operate on coastal waters 10 miles from Pakuhaji beach for 10 hours.
Table 4. Main Dimension of Vessel

\begin{tabular}{|l|l|}
\hline Description & Size \\
\hline Length over all (LOA) & 14.00 meters \\
\hline $\begin{array}{l}\text { Length of the Water Line } \\
\text { (LWL) }\end{array}$ & 12.53 meters \\
\hline Width, maximum (B max) & 3.10 meters \\
\hline Width, molded (B mld) & 3.00 meters \\
\hline Height, molded (D mld) & 1.60 meters \\
\hline Draft of ship (T) & 0.70 meters \\
\hline Driving machine & \begin{tabular}{l}
54 HP power) \\
\hline Speed
\end{tabular} \\
\hline Duration of operation & 10 hours \\
\hline Radius distance & $\begin{array}{l}80 \text { Nm (nautical } \\
\text { mile) }\end{array}$ \\
\hline
\end{tabular}

Table 5. Capacity of Vessel

\begin{tabular}{|l|l|}
\hline Description & Size \\
\hline Fish Hatch (Fish + Ice) & 4 Tons \\
\hline Fuel Oil & 220 liters \\
\hline Freshwater & 240 liters \\
\hline Crew / complement & 6 people \\
\hline $\begin{array}{l}\text { Gross Register Tonnage } \\
\text { (GRT) }\end{array}$ & $\begin{array}{l}10 \text { GT (gross } \\
\text { tonnage) }\end{array}$ \\
\hline
\end{tabular}

\subsubsection{Velocity and Distance Radius}

Official speed at 90\% Maximum Continuous Rating (MCR) with Sea Margine $15 \%$ main engine, with two thirds (2/3) fuel $\&$ fresh water capacity, 6 (six) people, on the basis of a clean / slippery hull, 8.00 knots in a state of calm water. At operational time with a full speed of 7.50 knots the condition of the engine is loaded at $90 \%$ MCR able to sail a total cruise distance of $80 \mathrm{Nm}$ with 10 hours endurance.

\subsubsection{Spatial In Hull}

In the hull, 3 (three) transverse waterproof bulkheads are installed dividing the hull of the ship into 4 (four) compartments, with the following arrangement :

1. Stern part

The steering gear holder and 1 (one) Freshwater Tank (FT) unit are placed in the stern niche, as shown in Table 4 below.

Table 7. Freshwater Tank (FT)

\begin{tabular}{|c|l|c|c|}
\hline No. & \multicolumn{1}{|c|}{ Description } & Number & Unit \\
\hline 1 & Complement & 6 & People \\
\hline 2 & Total engine power & 54 & $\mathrm{Hp}$ \\
\hline 3 & Roaming time & 0.42 & Day \\
\hline 4 & Crew & 16 & $1 / \mathrm{hari}$ \\
\hline 5 & Engine & 3.0 & $\mathrm{Kg} / \mathrm{Hp}$ \\
\hline 6 & Need for engine coolant & 195 & $\mathrm{Kg}$ \\
\hline 7 & $\begin{array}{l}\text { Drinking water \& sanitation } \\
\text { needs }\end{array}$ & 40 & $\mathrm{Kg}$ \\
\hline & Freshwater tank & 235 & $\mathrm{Kg}$ \\
\hline
\end{tabular}


2. Engine room

In the engine room placed 1 (one) unit of the Fuel oil Tank (FOT) as in Table 5 below. The room is equipped with adequate natural ventilation to maintain a maximum engine room temperature of $40^{\circ} \mathrm{C}$.

Table 8. Fuel oil Tank (FOT)

\begin{tabular}{|c|c|c|c|c|}
\hline \multirow{2}{*}{ Tanks } & \multicolumn{2}{|c|}{ Needs } & \multicolumn{2}{c|}{ Tanks Volume $\left(\mathrm{m}^{3}\right)$} \\
\cline { 2 - 5 } & $\begin{array}{c}\text { Weight } \\
(\mathrm{Kg})\end{array}$ & $\begin{array}{c}\text { Volume } \\
(\mathrm{L})\end{array}$ & Remaining & Expansion \\
\hline $\begin{array}{c}\text { Fuel } \\
\text { oil } \\
\text { tank } \\
\text { (FOT) }\end{array}$ & 158 & 186 & 204 & 213 \\
\hline Total & 158 & 186 & 204 & 213 \\
\hline
\end{tabular}

3. Fish Hatch

Two fish hatches for storage of fish and ice with the capacity as shown in Table 6 below.

Table 9. Fish Hatch

\begin{tabular}{|c|c|c|c|c|c|}
\hline \multirow{2}{*}{$\begin{array}{c}\text { Storage of } \\
\text { Fish (SF) }\end{array}$} & \multicolumn{2}{|c|}{ Volume $\left(\mathrm{m}^{3}\right)$} & $\begin{array}{c}\text { SWR } \\
76 \%\end{array}$ & $\begin{array}{c}\text { Fish } \\
57 \%\end{array}$ & $\begin{array}{c}\text { Ice } \\
43 \%\end{array}$ \\
\cline { 2 - 6 } & Bruto & Grain & Ton & Ton & Ton \\
\hline $\begin{array}{c}\text { Fish Hatch } \\
\text { No.1 }\end{array}$ & 6.81 & 5.45 & 4.14 & 2.36 & 1.78 \\
\hline $\begin{array}{c}\text { Fish Hatch } \\
\text { No.2 }\end{array}$ & 4.73 & 3.78 & 2.88 & 1.64 & 1.24 \\
\hline Total & 11.54 & 9.23 & 7.02 & 4.00 & 3.02 \\
\hline
\end{tabular}

4. Forepeak Room

The maritime equipment warehouse is placed in a bow niche room above the grating.

5. On the deck

The rudder house / bridge room functions as a room to control the ship and as a master bed for 1 (one) person, equipped with steering gear, navigation and communication equipment.

The accommodation room (ABK) functions as a ABK bed with a capacity of 6 (six) people.

\subsubsection{Equipment / Inventory}

Table 10. Mooring and Anchor

\begin{tabular}{|c|l|l|}
\hline No & Description & Size \\
\hline 1. & Anchor stick & $20 \mathrm{~kg}$, iron \\
\hline 2. & Anchor chain diameter & $16 \mathrm{~mm}$ \\
\hline 3. & Seckel & - \\
\hline 4. & Nylon anchor rope & $18 \mathrm{~mm}$ x 50 m \\
\hline 5. & Mooring ropes & $\begin{array}{l}14 \mathrm{~mm} \times 2 \text { pieces } @ \\
\end{array}$ \\
\hline 6. & Throw / throw rope & $8 \mathrm{~mm} @ 20 \mathrm{~m}$ \\
\hline 7. & Used tires & - \\
\hline 8. & Bow roller & - \\
\hline
\end{tabular}

Table 11. Safety Equipment

\begin{tabular}{|c|l|l|}
\hline No & Description & Unit \\
\hline 1 & Life jacket & 8 pieces \\
\hline 2 & Ring buoys & 2 pieces \\
\hline 3 & First aid kit containing medicines & 1 piece \\
\hline 4 & $\begin{array}{l}\text { Fire Fighting Equipment } \\
- \text { Powder type fire extinguisher } \\
2.5 \mathrm{~kg}\end{array}$ & 1 piece \\
\hline
\end{tabular}

Table 12. Navigation Equipment

\begin{tabular}{|c|l|l|}
\hline No & Description & Unit \\
\hline 1. & Mercury Compass 3" & 1 piece \\
\hline 2. & National Flag & 1 piece \\
\hline 3. & Signaling flags & 1 piece \\
\hline 4. & Map of the Indonesian sea & 1 set \\
\hline 5. & Ruler row & 2 pieces \\
\hline 6. & Term & 2 pieces \\
\hline
\end{tabular}

Table 13. Solar Panel Equipment

\begin{tabular}{|c|l|l|}
\hline No & Description & Unit \\
\hline 1. & Solar panels & $\begin{array}{l}2 \text { units above the } \\
\text { wheelhouse }\end{array}$ \\
\hline 2. & Battery & $\begin{array}{l}3 \text { units above the engine } \\
\text { room }\end{array}$ \\
\hline
\end{tabular}

Gear Equipment

- Gill net fishing gear equipment (Gill Net)

Table 14. Description of Gillnet

\begin{tabular}{cll}
\hline No & Description & Size / Unit \\
\hline 1 & Gill Nett D 6 & 2.5 inchi \\
2 & Gill Nett D 9 & 2.5 inchi \\
3 & Gill Nett D 12 & 2.5 inchi \\
4 & Gill Nett D 15 & 2.5 inchi \\
5 & Lifebouy Y 8 & \\
6 & Lifebouy Y 18 & \\
7 & Rope PE "SIGUL" (Blue) & 33
\end{tabular}

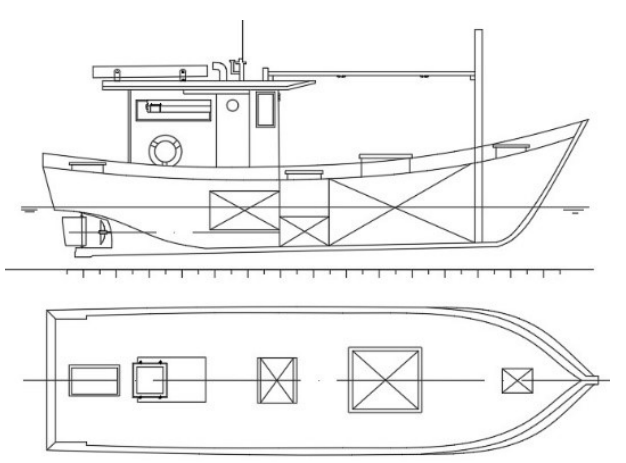

Fig. 3. General Arrangement of Fishing Vessel 10 GT

\subsection{Construction}

This fishing vessel is made with wood raw material. It is intended that the cost of shipbuilding is relatively cheap but the strength of construction is also relatively better, considering that in PPI Cituis the leaning area is 
rather narrow so that it often clashes between one ship with another. In the manufacture of wooden ships there are several things that need to be considered, including the composition of good quality materials, both for Lunas (keel), Bottom, Hull, Ivory / framework and other parts. In addition to the composition of the thickness of the material used is also a matter that needs attention [10].

All materials and equipment used for the manufacture of fishing vessels are new, with materials that have good quality test materials and are specifically used at sea.

The material used for the hull structure uses wood material with a minimum thickness of designation as follows : Lunas (keel), Base (Bottom), Hull (Hull), Ivory / Framework (Frame), Deck Floor (Deck), and Upper Building (Deck) Wheelhouse).

\subsection{Tonnage}

Tonnage is the volume of space on a ship with a Register Tonnage (RT) unit, where $1 \mathrm{RT}=100 \mathrm{ft}^{3}$ or equivalent to $2.83 \mathrm{~m}^{3}$.

Determination of ship GT according to the method of domestic measurement, is calculated in accordance with the provisions in the Decree of the Director General of Sea Transportation No. PY.67 / 1 / 16-02, using equation (1).

$\mathrm{GT}=0.25 \times \mathrm{V}(1)$

The value of 0.25 is the conversion value from cubic meters to tons of registers.

$\mathrm{V}=$ is the total contents of the room below the upper deck plus the rooms above the top deck that are perfectly closed measuring not less than 1 cubic meter.

$\mathrm{V}=(\mathrm{L} \times \mathrm{B} \times \mathrm{D} \times \mathrm{f})+\mathrm{V}$ of the upper building

$\mathrm{V}$ of the upper building is estimated to be $3 \times 2.5 \times 2.5$

$=30 \mathrm{~m}^{3}$

$\mathrm{V}=(\mathrm{L} \times \mathrm{B} \times \mathrm{D} \times \mathrm{f})+\mathrm{V}$ of the upper building

$=(13 \times 3.1 \times 1.8 \times 0.5)+17.75$

$=42.23 \mathrm{~m}^{3}$

So that :

$\mathrm{GT}=0.25 \times \mathrm{V}=0.25 \times 42.23=10.36$ close to $10 \mathrm{GT}$

$\mathrm{NT}=0.6 \mathrm{GT}=0.6 \times 10=6$

The calculation results of GT vessels 10.36 approaching the GT size of the desired vessel, namely the 10 GT Fishing Boat.

\subsection{Main Engine}

Table 15. Engine and Propulsion

\begin{tabular}{|l|l|}
\hline Description & Size \\
\hline Marine diesel engine & 1 unit \\
\hline Engine output (BHP) & $54 \mathrm{HP}$ \\
\hline Maximum rotation & 1,500 RPM \\
\hline Fixed propeller & 1 unit \\
\hline
\end{tabular}

\subsection{Stability}

Calculation of Rolling Period:

$0.5 * \mathrm{Cr}=0.373+0.023 *(\mathrm{~B} / \mathrm{d})-0.043(\mathrm{Lwl} / 100)=$ 0.4475
$\mathrm{Cr}=0.995$

$\mathrm{GM}_{\mathrm{T}}=1.354 \mathrm{~m}$

$T=\frac{C r^{*} B}{\sqrt{G M_{T}}}=8.64 \mathrm{~s}$

The ship's rolling period 8.64 (s) can be said to have a fairly comfortable stability in the motion of the ship and for the crew.

\subsection{Electric Power from Solar Panels}

The generated solar cell voltage will be used by the charge controller to charge the battery [11]. To turn on the load of AC devices (alternating current) such as navigation lights, television, radio, communication devices, etc., the battery current is supplied by the inverter [5].

Installation of solar power plants requires planning regarding power requirements, namely the amount of usage, the number of solar panels, the number of batteries [9].

Table 16. The Ship's Electrical Power Needs

\begin{tabular}{|c|l|c|c|c|}
\hline No. & Equipment & $\begin{array}{c}\text { Power } \\
\text { Average } \\
\text { (watt) }\end{array}$ & Quantity & $\begin{array}{c}\text { Amount } \\
\text { (Watt) }\end{array}$ \\
\hline 1 & $\begin{array}{l}\text { Room } \\
\text { lighting }\end{array}$ & 20 & 10 & 200 \\
\hline 2 & Spotlights & 100 & 1 & 100 \\
\hline 3 & Television & 75 & 1 & 75 \\
\hline 4 & Radio & 35 & 1 & 35 \\
\hline 5 & $\begin{array}{l}\text { Communicati } \\
\text { on tool }\end{array}$ & 75 & 1 & 75 \\
\hline 6 & Others & 10 & 1 & 10 \\
\hline & Total & & & 495 \\
\hline
\end{tabular}

The number of solar panels / solar cells needed, we count one panel to 100 Watts (calculation is 5 hours maximum solar power), The need for solar panels: 495 $/(100 \times 5)=1$ solar panel.

The number of batteries needed 12 Volts with 100 Ah each, Minimum battery requirements (batteries are only used $50 \%$ to meet electricity needs), thus we multiply the power needs 2 x fold: $495 \times 2=990$-Watt hour $=990 / 12$ Volt $/ 100 \mathrm{Amp}=2$ batteries $100 \mathrm{Ah}$, Battery requirements (with consideration of serving 2 days without sunlight): $495 \times 2 \times 2=1980$ Watt hour $=$ 1980/12 Volt / $100 \mathrm{Amp}=3$ batteries $100 \mathrm{Ah}$.

The number of solar panels / solar cell needed, one panel we count 100 Watt (calculation is 5 hours maximum solar power), The need for solar panels: $(1980 / 100 \times 5)=2$ solar panels.

\section{CONCLUSION AND SUGGESTION}

1. From the results of comparing the basic sizes and equipment, as well as calculating the electrical needs for the ship, the conclusion is obtained as a specification of the 10 GT fishing vessel as below.

2. Fishing vessels designed with the following specifications: 
Table 17. Spesification of Vessel

\begin{tabular}{|l|l|}
\hline Description & Spesification \\
\hline Total length (LOA) & 14.00 meters \\
\hline Molded height (D mld) & 1.60 meters \\
\hline Middle ship (T) & 0.70 meters \\
\hline Boat construction & Wood construction \\
\hline Tonnage: 10 GT & $10 \mathrm{GT}$ \\
\hline Driving machine & $54 \mathrm{HP}$ (horse power) \\
\hline Speed & $7-8$ knots \\
\hline Stability & PO 8.4 seconds \\
\hline Fishing gear & Gill Net \\
\hline Solar Panel Components & $\begin{array}{l}2 \text { solar panels and 3 } \\
\text { batteries }\end{array}$ \\
\hline Holding space capacity & 11.54 m3 \\
\hline $\begin{array}{l}\text { Maximum electricity } \\
\text { demand }\end{array}$ & 495 Watt \\
\hline Solar panels & 2 (two) units \\
\hline Battery & 3 units \\
\hline
\end{tabular}

3. Installing a solar panel system on a fishing vessel will save fuel consumption and increase the technical life of the battery.

\section{References}

[1] Anwar Limar Ramadhan, Ery Diniardi, Soni Hari Mukti. (2016). Design Analysis of Solar Power Generation System Capacity 50 WP. Journal of Engineering, Muhammadiyah University, 37 (2).

[2] Bachtiar M. (2006). Procedure for Installing a Solar Power System for Housing (Solar Home System). Journal of SMARTek Vol 4, No. 3

[3] Bambang Sudjasta, Yuhani Djaya. (2015). 10 GT Fishing Boat Design for Panimbang Pandeglang Waters. FT-UPNVJ Scientific Journal Bina Teknika Volume 11 Number 2 December 2015 Edition.

[4] Bambang Sudjasta, Purwo Joko Suranto. (2017). Design of Environmentally Friendly Water Buses as Alternative Means of Transportation in DKI Jakarta Province. FTUPNVJ Scientific Journal Bina Teknika Volume 13 Number 2 December 2017 Edition.

[5] Dafi Dzulfikar, Wisnu Broto. (2016). Optimization of Utilization of Household Electricity Solar Energy. Proceedings of the National Physics Seminar (E-Journal). Volume $\mathrm{V}$, October.

[6] David Setia Maradong. (2016). The Big Potential of Indonesian Capture Fisheries. Article of Maritime Relations of the Cabinet Secretariat.

[7] Directorate General of Capture Fisheries, KKPRI, (2014), Book of Capture Fisheries Statistics Annual Report 2014.

[8] Iswadi Nur, 2013, Simple Method for Choosing the Type of Small Boat Hull According to Its Function Based on Suitable Stability Considerations in order to Avoid Accidents at Sea, FT-UPNVJ Scientific Journal
Bina Teknika Vol. 9 Number 2 December Edition.

[9] Jatmiko, Angga. (2012). Intensity of Sunlight Against Solar Cell Panel Output. RAPI XI FTUMS National Symposium.

[10] Munro-Smith. (2016). Naval Architecture. Ernest Benn Limited, London.

[11] Prasetyo, R. (2012). Titania-Based Solar Cells As Alternative Electrical Energy Sources. Proceedings of the National Seminar on Research, Education and Application of MIPA, Faculty of Mathematics and Natural Sciences, Yogyakarta State University, July 2, 2012.

[12] Soekarsono, (2002), Ship Systems and Equipment, Pamator Pressindo, Jakarta. 